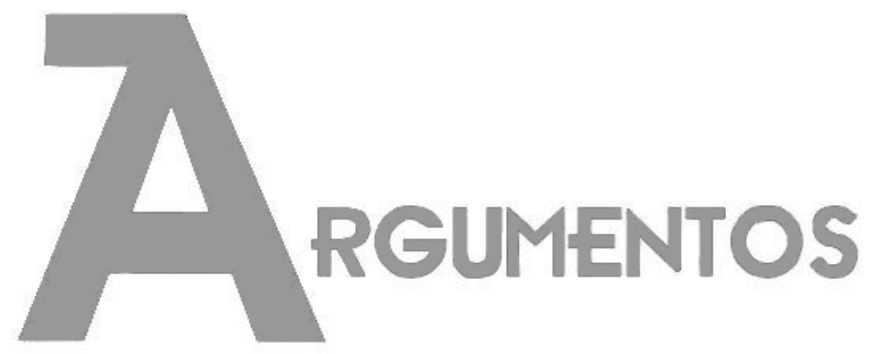

Vol. 16, n. 1, jan./jun. 2019 ISSN: 2527-2551 (online)

\title{
Emergência urbana: criação de espaço público e o nascimento do "Parque Minhocão" na cidade de São Paulo
}

João Pedro Campos ${ }^{1}$

Recebido em: 31/01/2019

Aprovado em: 30/04/2019

Resumo: Neste artigo analisamos a emergência do Parque Minhocão, em São Paulo, a partir das interações e engajamentos que os habitantes da cidade realizam com esse famoso viaduto da capital. Observamos que o espaço não é algo de significado fixo, mas que emerge continuamente e de forma espontânea das ações não planejadas das pessoas que recebem o espaço historicamente constituído e continuam a moldá-lo através das demandas da sociabilidade de suas vidas. Apontamos que no caso do Parque Minhocão a dimensão criativa e lúdica é elemento central para se entender como se dá o processo de democratização de áreas privadas ou restritas da cidade e que são incorporadas pelas pessoas como espaço público, sem necessariamente haver a mediação do Estado. O Minhocão representa no imaginário paulistano um projeto urbanístico de insucesso que degradou a cidade, notamos, porém, que em seu dia a dia as pessoas não olham apenas para as imperfeições desse viaduto, integrando-o às suas vidas e atribuindo-Ihe qualidades.

Palavras-chave: espaço urbano; antropologia urbana; arte urbana; Parque Minhocão.

\section{Emergencia urbana: creación de espacio público y el nacimiento del "Parque Minhocão" en la ciudade de São Paulo}

Resumen: En este artículo analizamos la emergencia del Parque Minhocão, en São Paulo, a partir de las interacciones y compromisos que los habitantes de la ciudad realizan con ese famoso viaducto de la capital. Observamos que el espacio no es algo de significado fijo, sino que emerge continuamente y de forma espontánea de las acciones no planificadas de las personas que reciben el espacio históricamente constituido y continúan a moldealo a través de las demandas de la sociabilidad de sus vidas. Señalamos que en el caso del Parque Minhocão la dimensión creativa y lúdica es elemento central para entender cómo se da el proceso de democratización

\footnotetext{
1 Graduando em Direito pela Universidade de São Paulo - São Paulo, Brasil. Mestre em Sociologia pela Universidade Federal Fluminense - Rio de Janeiro, Brasil. E-mail: < camposjpl@gmail.com >. ORCID: https://orcid.org/0000-0002-3590-489X.
} 
de áreas privadas o restringidas de la ciudad y que son incorporadas por las personas como espacio público, sin mediación del Estado. El "Minhocão" representa en el imaginario paulistano un proyecto urbanístico de fracaso que degradó la ciudad, notamos, sin embargo, que en su día a día la gente no mira sólo las imperfecciones de ese viaducto, integrándolo a sus vidas y atribuyéndolole cualidades.

Palabras-clave: espacio urbano; antropología urbana; arte urbano; Parque Minhocão

\title{
Urban emergency: creation of public space and the birth of the "Minhocão Park" in São Paulo city
}

\begin{abstract}
In this article, we analyze the emergence of Parque Minhocão, in São Paulo, based on the interactions and engagements that the inhabitants of the city make with this famous viaduct. We note that the Minhocão, as a space, is not something of fixed meaning, but it continually emerges from unplanned actions carried out by people who receive it historically and have continued to shape it to adapt it to its vital demands. We point out that in the case of the Parque Minhocão Park, the creative and playful dimension is a constituent element of its process of genesis, which we identify with the democratization of urban areas without necessarily having the mediation of the State. The Minhocão represents in the São Paulo imaginary an unsuccessful urban project that degraded the city, but we note that in their daily life people do not only look at the imperfections of this viaduct, but create strategies to integrate it in a healthy way to their daily life.
\end{abstract}

Keywords: urban space; urban anthropology; urban art; Parque Minhocão.

\section{Introdução}

Neste artigo analisamos através de um estudo de caso o surgimento do chamado "Parque Minhocão", em São Paulo, localizado no viaduto João Goulart, que liga a Zona Oeste da cidade ao Centro e dali à Zona Leste. Interessa-nos refletir sobre a utilização que as pessoas fazem dos espaços urbanos abertos e como as formas de estarem nesses lugares os transformam. Os usos, pensamos, têm a potência de tornar uma passagem para carros em área de lazer, cultura, brincadeiras, artes, política e esportes para cidadãos de uma metrópole carente de aparelhos públicos de uso coletivo. Indicamos neste artigo de que maneira, no decorrer das últimas quase cinco décadas, o colosso viário que ficou popularmente conhecido como Minhocão perdeu sua definição de via asfaltada elevada e adquiriu outros sentidos.

Importa-nos mostrar que tal mudança não se deu pelo acordo de urbanistas, engenheiros de tráfego ou da municipalidade, que teriam concluído que São Paulo já não mais necessitava do viaduto que estudamos; fosse assim, o Minhocão teria sido como muitos gostariam - simplesmente desmontado. Ao contrário, ao nos debruçarmos sobre o Minhocão, sua história e seus usos, vemos como os espaços da cidade não 
possuem significado em si, mas que são produto daquilo que as pessoas neles realizam. Para tanto, dividimos o artigo em dois blocos utilizando os conceitos de: "lúdico" e "luta". O primeiro diz respeito àquilo que dá prazer, às recreações, brincadeiras, lazeres e artes, entendidos como as ferramentas da criação e modificação que os habitantes da cidade fazem e fizeram do elevado praticamente desde sua fundação. E o segundo aponta as controvérsias e engajamentos políticos e jurídicos dos atores diretamente interessados no destino do Minhocão.

O elevado João Goulart foi inaugurado em janeiro de 1971 sob o nome de "Via Elevada Artur da Costa e Silva", em homenagem ao presidente do Brasil do período da ditadura militar (1964 - 1985). Essa via expressa elevada fora concebida como solução para problema do trânsito em São Paulo, aproximando as Zona Leste e Oeste através da ligação da Praça Roosevelt, no Centro, à Avenida Francisco Matarazzo. Afetuosamente chamada de Minhocão pelos paulistanos, por seu formato de minhoca gigante de concreto armado, a via de 3,4 km que passa por cima das avenidas Amaral Gurgel, São João e General Olímpio da Silveira se chocou/a com a vida dos habitantes da cidade e se associou/a à paisagem humana de São Paulo.

Desde sua fundação o Minhocão transforma continuamente os modos de vida no Centro e em Santa Cecília, separa com um traço de concreto o rico bairro de Higienópolis do outrora rico bairro de Campos Elíseos e impulsiona a expansão imobiliária na região da Barra Funda. Aberto de segunda a sexta das $7 \mathrm{~h}$ às $20 \mathrm{~h}$, o Minhocão traz barulho e poluição à vida dos moradores de seu entorno, desgasta o cotidiano e representa o estado de conflito que os habitantes de São Paulo mantém com a cidade, que não está planejada para o bem-estar humano e tampouco acontece através da participação democrática das pessoas em sua organização.

O fracasso do Minhocão enquanto solução viária ficou evidente desde sua abertura. O transtorno do trânsito foi apenas transferido para um piso superior sobre a rua, a cinco metros de distância dos milhares de apartamentos ao redor do elevado. Uma onda permanente de barulho, calor e poluição invadiu as casas pelas janelas, que tiveram de ser fechadas para tornar a vida possível nesse novo deserto criado na cidade. Os imóveis da região foram desvalorizados e com a mudança de muitas famílias, os prédios passaram a ser utilizados como sala de escritórios, serviços e comércio. A parte de baixo do Minhocão nunca mais recebeu um raio de luz solar e se tornou ins egura e 
Dossiê | Emergência urbana: criação de espaço público e o nascimento do "parque minhocão" na cidade de São Paulo (CAMPOS, João Pedro)

escura mesmo durante o dia. Essa obra monumental, imposta à sociedade em um período autoritário, degradou o espaço urbano e a vida das pessoas e é popularmente chamada de cicatriz no rosto da cidade.

Ocorre, porém, o fato da realidade da cidade ser um processo, tendo o Minhocão desde o dia de sua fundação começado a se transformar em algo distinto daquilo que fora concebido para ser. Analisaremos neste artigo a criação dessa outra coisa, o Parque Minhocão, espaço urbano democrático, espaço público, que não é planejado e emerge da percepção, organização e relação entre as pessoas e o espaço que habitam. Ao invés de olhar apenas para as imperfeições do Minhocão - que existem - os habitantes da cidade lhe dão usos que mudam o status, a qualidade, o significado da via expressa através da interação e o engajamento que realizam com o viaduto e seu entorno. $\mathrm{O}$ Minhocão é um fenômeno urbano de emergência espontânea do espaço que revela a dimensão criativa da cidadania, entendida como atributo democrático do habitante de um determinado Estado, de uma cidade enquanto corpo político, uma pólis.

Analisamos o espaço não como um fato da natureza, descritível por seus atributos físicos mais ou menos modificados pela ação humana, tampouco como simples fato da "cultura", mas sim como produto (Lefebvre, 2006). Considerar o espaço como um produto significa não tomá-lo como coisa, e sim como um conjunto de relações que reúnem o mental, o cultural, o físico, o social e o histórico e também o arquitetural, o territorial e o urbanístico. Ao considerar o espaço do Minhocão como um produto de relações, descobrimos que suas dimensões não se limitam aos $3,4 \mathrm{~km}$ que o constituem e que sua existência funcional enquanto via expressa para automóveis hoje se encontra no limiar da perda de sentido.

Atualmente os habitantes da cidade vivenciam o resultado de quase cinquenta anos de transformações no elevado, de um trambolho autoritário de concreto para um parque urbano de matéria incerta, algo plástica e moldável em contínua formação. O Parque Minhocão já é uma realidade. Mas também é real o intenso tráfego de automóveis durante o dia. Quem observa o elevado em funcionamento em dado horário não encontrará a mesma coisa ao retornar e observar novamente em outro momento, talvez à noite ou aos finais de semana. 
Para entendermos como se dá o processo de geração do Parque Minhocão também estudamos sua história do ponto de vista das demandas da reprodução da vida cotidiana, inseridas na razão global do sistema capitalista, que incorpora a cida de de São Paulo a uma lógica mundial (Harvey, 2012; Lefebvre 2006). A reflexão sobre a política para o Minhocão nos ajuda a compreender como foi possível que na década de 1970 uma solução de engenharia e urbanismo há muito superada nos países democráticos, comprovadamente degradante da vida urbana (Jacobs, 2011), tenha sido colocada de pé e celebrada por autoridades da época, não obstante a crítica de jornais ${ }^{2} \mathrm{e} d a$ sociedade civil, sobretudo por parte daqueles cuja vida doméstica seria invadida pelo trânsito da cidade.

A maior obra viária da América Latina no período ${ }^{3}$, projetada para livrar os paulistanos de um problema que ainda hoje os assola, foi um erro de planejamento urbano muito danoso à cidade, que não considerou o impacto humano e social da de sua execução, além de não resolver o trânsito, agora elevado. Apesar de todas as adversidades, o Minhocão continua de pé e em funcionamento. Colossal, de concreto, à janela dos moradores que há quase cinquenta anos suportam o incessante fluxo de carros, a barulheira das buzinas, a fumaça dos escapamentos e o calor dos motores. Construído sem participação democrática, o Minhocão representou a chegada de um desastre na vida das pessoas em função de um modelo de cidade que privilegia o transporte automotivo individual sobre outras soluções possíveis para a mobilidade urbana.

\footnotetext{
2 Manchete do jornal O Estado de São Paulo de 01/12/1970 dizia "Elevado, o triste futuro da avenida"; Em 23/01/21971 o mesmo jornal agora perguntava ao leitor "Quem diz que o Minhocão é útil?". Disponível em: <https://acervo.estadao.com.br/pagina/\#!/19701201-29342-nac-23-999-23not/busca/Minhoc\%C3\%A3o>

3 Especial Minhocão: um quarentão de futuro incerto. Disponível em: $<$ http://www.saopaulo.sp.leg.br/especiaiscmsp/especial-minhocao/>
} 


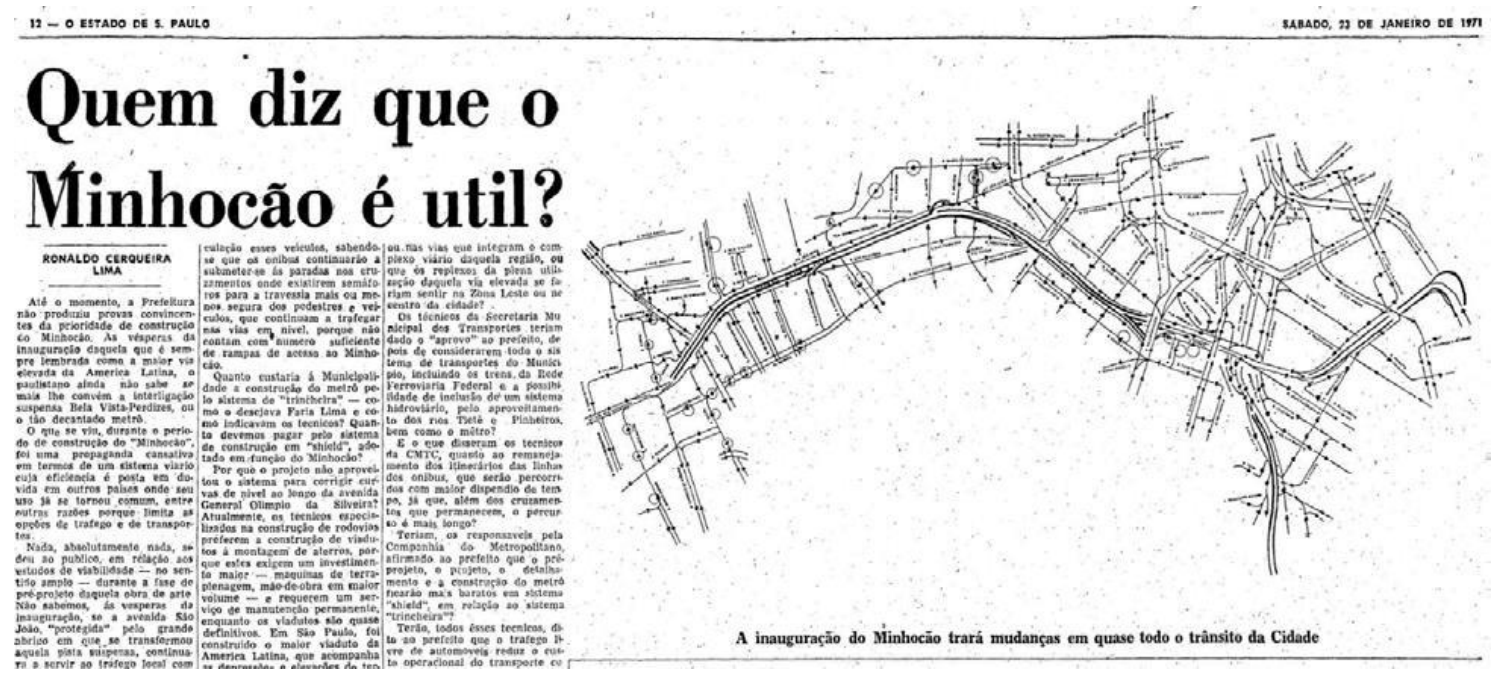

Figura 1. Coluna de Opinião do jornal O Estado de São Paulo, 1971. ${ }^{4}$

A realidade da cidade, porém, repetimos, é um processo. Durante os cinco primeiros anos de existência do Minhocão ele foi utilizado unicamente como via expressa para automóveis. Não havia a restrição de horários como hoje a conhecemos até $1976^{5}$, quando se determinou seu fechamento para carros da meia noite às cinco da manhã, com o objetivo de reduzir o índice de acidentes noturnos e garantir o silêncio da madrugada aos moradores. Essa data representa uma virada simbólica histórica para o Minhocão.

Com as pistas elevadas livres de automóveis, os moradores da região passaram a utilizá-las para o lazer, praticar esportes, passear com os animais, para encontrar os namorados, para utilizarem drogas sem a ameaça da repressão policial, como atalho de uma parte da cidade para a outra ou simplesmente passagem. Quando o Minhocão foi fechado para carros na madrugada e aberto para as pessoas, ele já havia começado a se transformar em espaço democrático, moldado pela vontade pública mais ou menos organizada, que pressionara a prefeitura municipal a atender a demanda básica do silêncio para o descanso.

Os primeiros frequentadores noturnos do Minhocão, pedestres ou de bicicleta, descobriram o caminho por uma via enorme, de proporções não humanas, quase

4 Notícia do jornal $O$ Estado de São Paulo de 23/01/1971. Disponível em: $<$ https://acervo.estadao.com.br/noticias/acervo,como-era-sao-paulo-sem-o-minhocao,9070,0.htm> 50 elevado João Goulart: a história do Minhocão. Disponível em: <http://www.saopauloinfoco.com.br/construcao-elevado-costa-e-silva/> 
Dossiê | Emergência urbana: criação de espaço público e o nascimento do "parque minhocão" na cidade de São Paulo (CAMPOS, João Pedro)

sempre reta, que permite que a vista alcance quilômetros à frente, ladeada por elegantes edifícios históricos. Não havia e ainda hoje não há infraestrutura sobre as pistas, exceto os postes de iluminação e as grades laterais, feitas para proteger carros e não pessoas. Trata-se basicamente de espaço aberto livre: livre do empreendedor imobiliário, livre da opressão visual da cidade que enclausura - a paisagem a partir do Minhocão é espaçosa e desafogada -, livre do ol har vigilante e repressivo da polícia, livre da violência dos automóveis sobre os pedestres. Um solo fértil para a (cri)ação humana não planejada.

As diversidades de uso e significados atribuídos ao Minhocão e a pressão exercida por organizações da sociedade civil em defesa da constituição de um parque sobre a via, concorreu para que as gestões municipais passassem a humanizá-lo em termos legais. No ano de 1989, em um momento mais democrático, foi diminuído o período de funcionamento do Minhocão para os carros, passando a ser das $06 \mathrm{~h}$ às $21 \mathrm{~h} 30$, ampliando-se o tempo de uso pelas pessoas que, quanto mais o utilizavam mais o transformavam em algo distinto de uma via expressa. Neste mesmo ano o Minhocão passou a ser fechado aos domingos, fator decisivo para o surgimento do parque, pois aberto aos pedestres durante o dia, permitiu que pessoas de outras regiões da cidade e outras faixas etárias, como crianças, também o utilizassem. Atualmente o Parque Minhocão existe enquanto legislação, incluído no Plano Diretor de São Paulo em 2014 e sancionado em 2018 como lei.

Este presente estudo sobre a transformação de um espaço autoritariamente imposto em espaço público é produto de caminhadas e corridas pelo Minhocão. Incursões na madrugada, avistamentos pela janela, participação na vida cotidiana do elevado, atropelamentos, inseguranças, perspectivas e sonhos de cidade e urbanismo. O Minhocão que conhecemos para produzir este texto está no limiar de uma transformação inevitável, mas que vem forçosamente sendo adiada por razões apresentadas neste artigo. Inserimo-nos em um debate vigoroso que hoje ocorre em São Paulo: que fazer com o Minhocão?.. Essa herança urbanística de períodos não democráticos... A resposta a essa questão, acreditamos, vem sendo dada através dos usos reais do elevado, e não em debates que - novamente - não colocam as pessoas no centro deste assunto. Assim, este artigo procura contribuir com o debate público sobre 
o Minhocão, retirando alguns entulhos que pesam sobre a produção democrática das cidades em que habitamos.

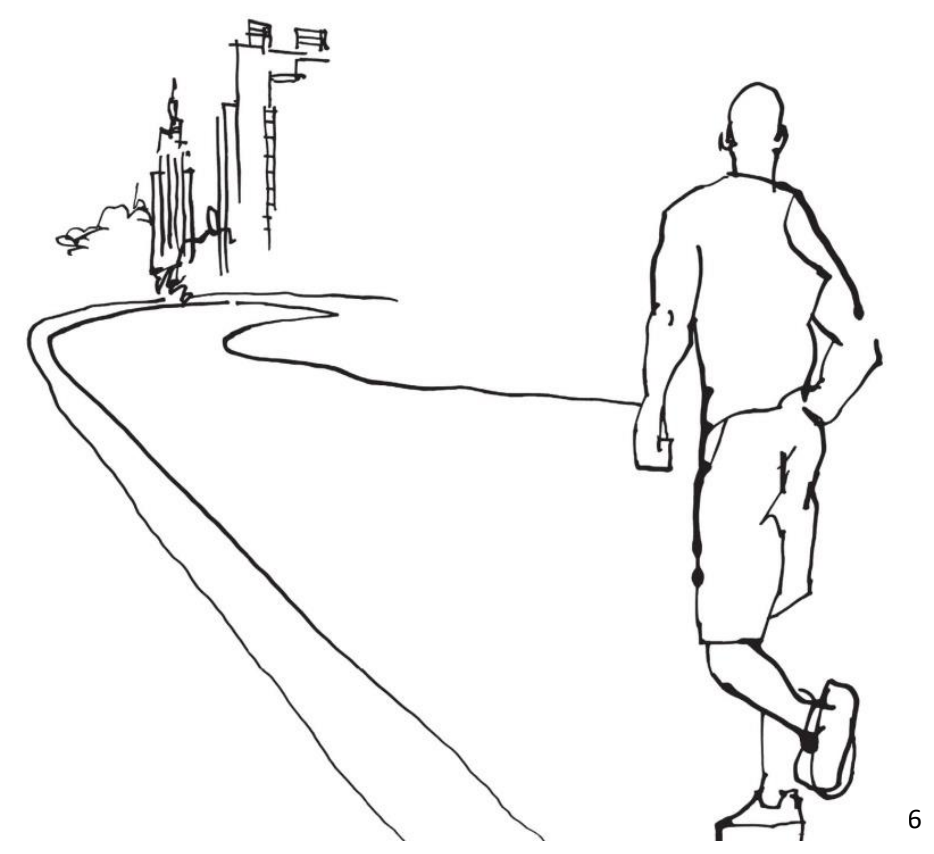

\section{O lúdico}

O organismo do espaço Um envelope bioenergético Sustentado por rendas arquitetônicas acidentais De sulcos materiais em intervalos irregulares Locais, pontos de ebulição para os desfiles Cívicos sociais psíquicos da necessidade inconsciente

Assim, ruínas de qualidade, lixo resgatado Interlúdios pal páveis, recintos suficientemente momentâneos Para fornecer um proscênio para o oceano.

Lena Kilina, $2018 .^{7}$

\footnotetext{
6 Paulo Von Poser, 2015. Gravura retirada do livro "Um viaduto chamado Minhocão".

7 KILINA, Lena. Estado de Jogo. Performance. São Paulo, 2018. Disponível em: <https://vimeo.com/295309465>
} 
Dossiê | Emergência urbana: criação de espaço público e o nascimento do "parque minhocão" na cidade de São Paulo (CAMPOS, João Pedro)

O que as pessoas fazem nos espaços da cidade? E por que elas estão fazendo o que fazem? Por que nesse espaço e não em outro espaço? O que é um espaço? Em particular, o que é o espaço urbano? LeFebvre (2006) diz que o espaço, junto com o tempo, é um dos aspectos principais da segunda natureza, processo e produto humano. Walter Benjamin chamava a cidade de "realização do antigo sonho humano do labirinto" (Benjamin, 2000, p. 203), um permanente estado de jogo, redefinição, impermanência e inconstância da forma, como um labirinto de paredes móveis. E quem movimenta as paredes desse labirinto? Quem são os principais atores da transformação do espaço na sociedade paulistana a qual nos dedicamos a estudar, capital do capital financeiro? E qual é o alcance e efetividade das decisões e ações desses principais atores sobre o espaço?

Por um lado, podemos dizer que o espaço urbano é o planejado, em que pese a ação dos proprietários da terra e os objetivos de reprodução da sociedade capitalista (Corrêa, 1999); e por outro lado o espaçoé o vivido, a ação humana que gera e engendra o espaço, não como algo externo ao homem, uma res extensa diante de uma res cogitans cartesiana, mas o espaço como humanidade, história, em uma cultura que "figura na mente sua construção antes de transformá-la em realidade" (Marx, 2017, p. 327). O espaço urbano é uma realidade complexa feita de relações dinâmicas que transformam o espaço como as "gerações mudam os valores e (...) se reorganizam em um contínuo processo de criação" (Cole, 2008) e representam uma comunidade através da visualidade e do discurso da cidade (Argan, 1995).

Todos esses autores apontam, por caminhos argumentativos diversos, que 0 espaço é um produto, criação. Destacamos neste estudo sobre o Minhocão aspectos relativos ao papel da criatividade e do jogo no seu processo de emergência enquanto parque. Assinalamos que essa criatividade também possui um conteúdo político, pois quando os habitantes da cidade geram espaço através do uso e o reivindicam para si com esse novo conteúdo, o fazem em dis puta com outros atores interessados no mesmo espaço. Tratamos principalmente do Estado, pois o Minhocão é uma propriedade pública, submetida a poderes administrativos e políticos da municipalidade. De modo que a concretização do processo do parque passa pela prefeitura, que em duas datas recentes Ihe conferiu existência jurídica. Primeiro ao incluir a previsão de criação do 
Parque Minhocão no Plano Diretor de São Paulo no ano de 2014 e em seguida ao autorizar sua criação em 2018 através da Lei 16.833/2018 ${ }^{8}$.

As relações jurídicas sob as quais o Minhocão está submetido enquanto propriedade do Estado o torna sujeito à política públicas para a coletividade, que variam no tempo e são expressão, entre outros, do nível de organização da sociedade civil e da correlação de forças entre os diferentes espectros políticos. Ao observarmos as transformações do Minhocão, vemos que nos últimos anos se acelerou o processo de reconhecimento jurídico-político-administrativo de seu uso enquanto parque.

A inclusão do projeto "Parque Minhocão" no Plano Diretor de 2014 aconteceu sob a prefeitura de Fernando Haddad (PT), em um momento em que a sociedade brasileira atravessava manifestações populares nas quais se demandava o chamado direito à cidade, compreendendo direito à mobilidade, permanência e uso (Vainer, 2013). Já a aprovação da Lei 16.833/2018 - Lei Parque Minhocão - aconteceu nas últimas semanas da curta administração municipal de João Dória (PSDB) que se comprometera em avançar projetos relacionados à criação de novos parques (Parque Augusta, Parque Minhocão, Parque Campo de Marte, entre outros), mas que também buscou alienar a administração pública de outros parques já existentes, como o lbirapuera que está em processo de venda.

Apesar do inegável avanço representado pela aprovação da Lei 16.833/2018, o prefeito João Dória vetou o importante item aprovado pelos vereadores que determinava o fechamento integral do Minhocão nas férias escolares de julho e janeiro. ${ }^{9}$ Além disso, a gestão Dória conduziu a campanha "Cidade Linda", que se ocupou de apagar grafites e outras intervenções estéticas urbanas anônimas constituintes do significado de ser paulistano e pertencer a esse lugar.

Uma das particularidades da arte que ocorre na área aberta da cidade é que comumente seus atores se envolvem em disputas políticas, mesmo que não tenham se dirigido para o espaço aberto com essa intenção. Isso acontece devido a luta pela

\footnotetext{
${ }^{8}$ Lei 16.833/2018 - Cria o Parque Municipal do Minhocão e prevêa des ativação gradativo do El evado João Goulart. Disponível em: <http://legislacao.prefeitura.sp.gov.br/leis/lei-16833-de-7-de-fevereiro-de2018>

9 Doria autoriza a criação do Parque Municipal do Minhocão. Disponível em: $<$ http://agenciabrasil.ebc.com.br/geral/noticia/2018-02/doria-sanciona-lei-que-institui-o-parquemuncipal-do-minhocao>
} 
Dossiê | Emergência urbana: criação de espaço público e o nascimento do "parque minhocão" na cidade de São Paulo (CAMPOS, João Pedro)

definição do significado e dos usos dos espaços na cidade, que cruzam razões econômicas, políticas, culturais, históricas, identitárias, entre outras. Por isso, a arte de rua, como a vivenciamos hoje, é uma expressão altamente politizada em sua forma de existência, que se relaciona a permanência em um aparelho urbano - calçada, parede, pilastra, escada, etc - cuja identificação enquanto disponível para a realização de arte não é consenso entre os atores do espaço, gerando, assim, conflito (Campos, 2017). Os grafites e pixos que tradicionalmente colorem as colunas de sustentação do Minhocão também foram alvo da política pública intolerante da prefeitura de João Dória com a arte de rua, foram pintados de cinza.

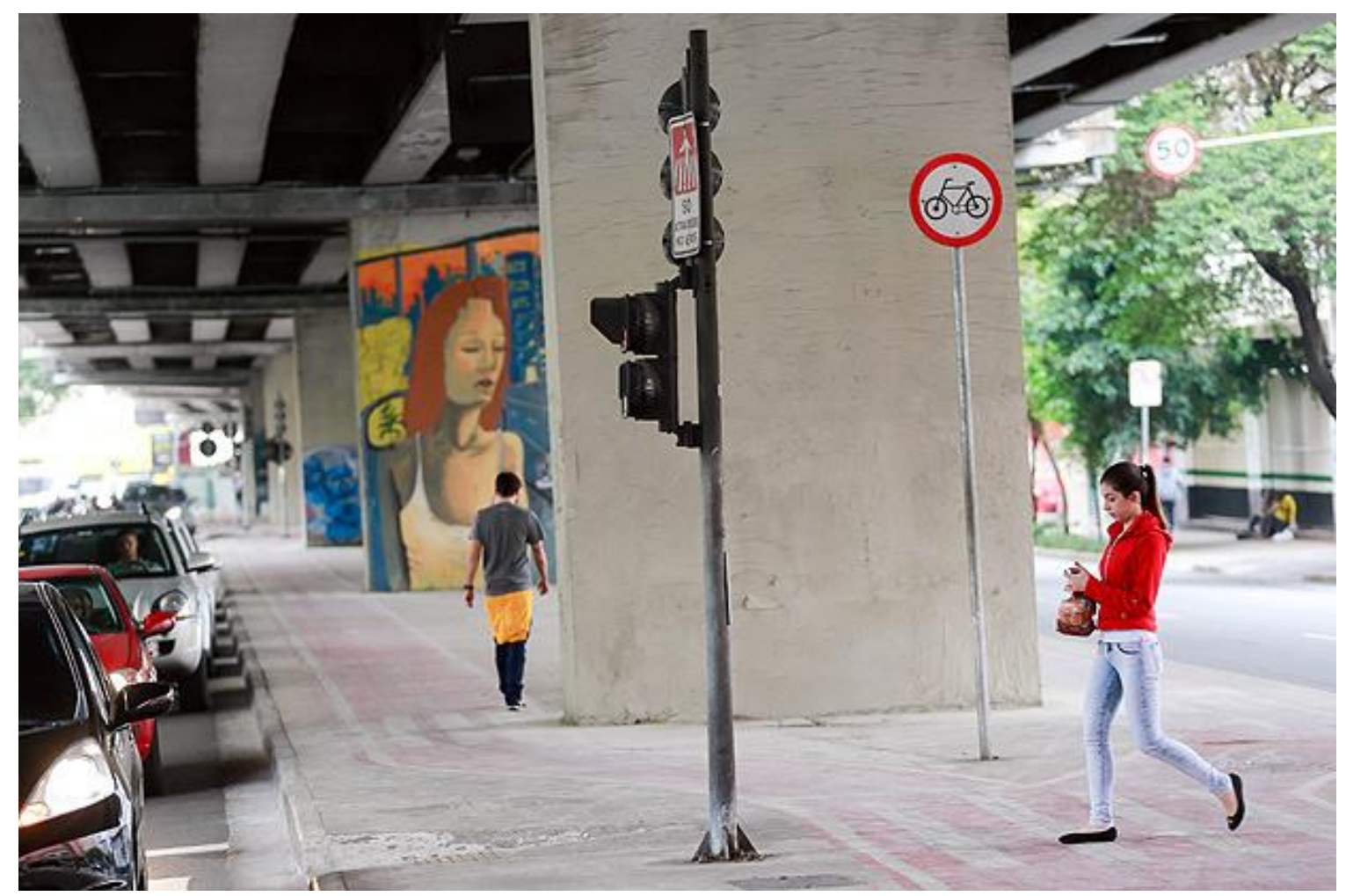

Figura 2. "Apagaram tudo, pintaram o muro de cinza" (MONTE, 2000). Colunas de sustentação do Minhocão são pintadas de cinza por agentes da prefeitura municipal de São Paulo, no ano de 2017. ${ }^{10}$

A decisão da prefeitura de apagar grafites e pixos em pontos importantes de arte de rua da cidade não foi apenas desacertada e impopular, mas infrutífera, por não

10 "Gestão Dória pinta as colunas do Minhocão e apaga parte dos grafites". Disponível em: $\quad<$ https://www1.folha.uol.com.br/cotidiano/2017/11/1934319-gestao-doria-pinta-as-colunas-dominhocao-e-apaga-parte-dos-grafites.shtml > Acesso em: 25/10/2018 
considerar que a cidade é um processo - como afirmamos neste artigo. A famosa frase de enfrentamento dos pixadores - "vamos ver quem tem mais tinta" - novamente se mostrou válida pois, algumas horas após os muros da cidade e as colunas do Minhocão serem pintados de cinza, eles apareceram novamente coloridos de escritos e desenhos.

Um dos símbolos da intolerância irracional da prefeitura com a arte de rua foi o apagamento dos murais do projeto Giganto, liderado pela fotógrafa Raquel Brust, iniciado em 2008, que consistia na colagem de fotografias tamanho gigante de rostos de moradores de São Paulo nas colunas de sustentação do Minhocão. Os artistas do projeto Giganto responderam ao apagamento de seus murais colando uma nova fotografia, dessa vez não na parte de baixo do elevado, mas na fachada lateral de um dos mais importantes edifícios da região, a Casa do Estudante da São Francisco, charmoso prédio da década de 1940, que foi residência de, entre outros, Michel Temer. ${ }^{11}$

${ }^{11}$ Casa do Estudante da São Francisco. <https://www.casadoestudantesf.com.br/> 


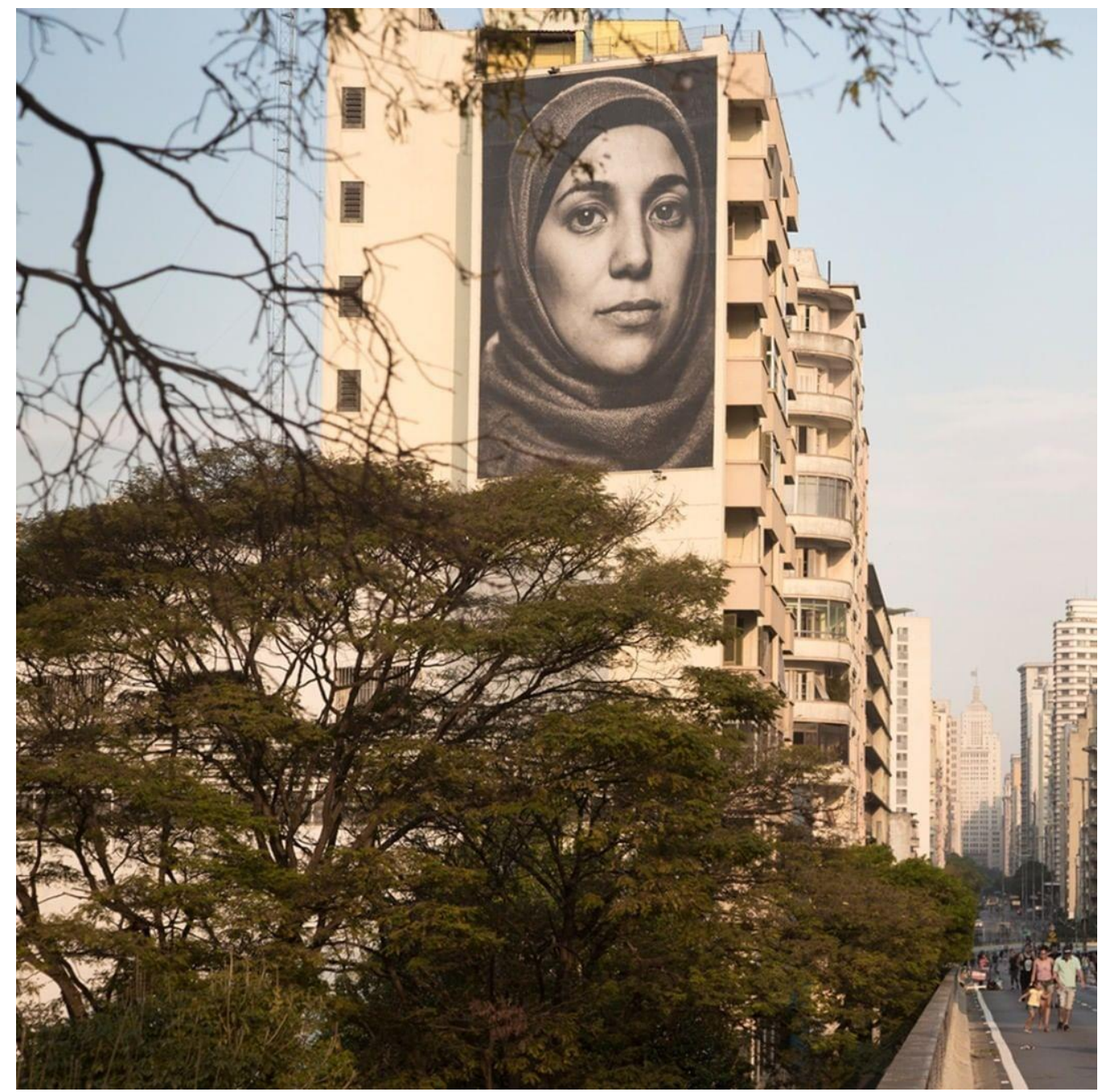

Figura 3. Fotografia de Salsabil Matouk, refugiada síria habitante de São Paulo, realizada em 2018 como parte do projeto Giganto, da fotógrafa Raquel Brust, na fachada lateral da Casa do Estudante da São Francisco, que ladeia o Minhocão. ${ }^{12}$

O componente visual da cidade, a imagem de seus lugares, zonas e territórios, é parte central da vida mental dos que a habitam (Lynch, 1999), e que constroem o urbano a partir das condições históricas herdadas e de uma memória narrada, matéria prima do conhecimento de si e do mundo, mobilizada no momento da ação sobre o espaço (Rocha; Eckert, 2013). Essa ação é histórica, isto é “ela é obra de uma história de pessoas e de grupos bem determinados que realizam essa obra [a cidade] nas condições históricas" (Lefebvre, 2001, p.47). A cidade é como uma linguagem que recebemos antes de modificá-la; sua dimensão física representa a materialização de uma sucessão de

\footnotetext{
12 Fotografia da intervenção Giganto no edifício da Casa do Estudante do Largo de São Francisco, 2018. Disponível em: $\langle$ https://deskgram.net/explore/tags/intelhackthecity $>$
} 
ações e decisões, condutas, mensagens, códigos sobre o espaço urbano e no espaço urbano realizados ao longo da história.

Do ponto de vista da imagem da cidade, a progressiva abertura do Minhocão para uso livre revelou aos habitantes uma nova dimensão visual de São Paulo na qual a vista alcança a distância. Ao enxergar amplamente a cidade, seus habitantes criam condições para se projetarem na paisagem, conceber e realizar sua transformação, como têm feito ao longo das décadas. As fachadas laterais de prédios que ladeiam o Minhocão, por exemplo, recebem intervenções estéticas tamanho gigante que são feitas para serem vistas pelos usuários do elevado. Os mais comuns são os painéis, pinturas de grandes dimensões que geralmente carregam mensagens políticas: o desenho de uma flor rompendo o asfalto, a representação da luta por direitos da comunidade transgênera, uma cabeça humana caótica composta de vias e viadutos embaraçados, a face de uma imigrante síria refugiada de guerra e mais recentemente o mural em comemoração ao centenário de nascimento de Nelson Mandela.

Uma dimensão fundamental para se pensar o surgimento e a popularização das intervenções visuais nas fachadas dos prédios ao redor do Minhocão é que elas serão vistas pelas pessoas, e foram feitas por essa razão. O público veio antes da obra, neste caso. A obra de arte que acontece no Minhocão não acontece como um objeto independente e alheio a seu meio, mas como elemento capaz de interagir e gerar espaço urbano. Tem-se exemplo desse engajamento entre arte/artistas e espaço urbano em ações do grupo de teatro "Esparrama", que realiza peças teatrais infantis no Minhocão e articula os elementos do viaduto com suas apresentações: a janela do prédio se transforma em espaço cênico (palco), o piso do Minhocão serve ao mesmo tempo como a plateia, de onde os passantes assistem a peça e de palco, à medida que os artistas também atuam sobre o Minhocão e não apenas de frente para ele. 


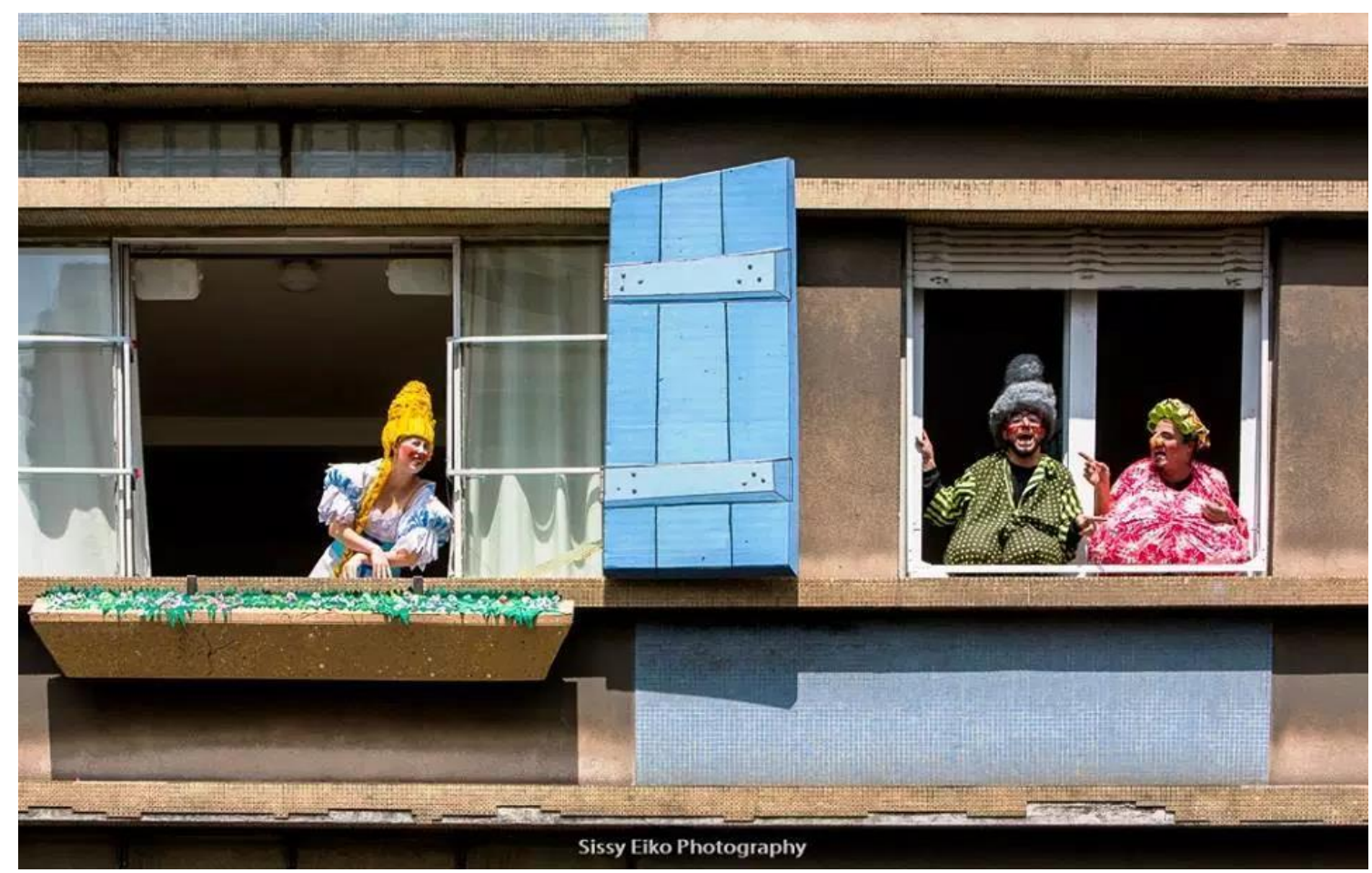

Figura 4. Apresentação do grupo teatral Esparrama em janela aberta para a pista do Minhocão, em 2016. ${ }^{13}$

Estar no Minhocão é uma atitude transformadora, pois sua definição está em jogo desde o dia 25 de janeiro de 1971, quando o grande trânsito de sua inauguração fora prenúncio de um desastre sócio-urbanístico. ${ }^{14}$ Os usos concretos dados a essa via elevada transformaram um deserto de origem autoritária em espaço vivo e democrático, socialmente saudável, que incorpora as demandas das pessoas e faz sentido na reprodução de suas vidas cotidianas. Hoje se discute qual será a forma futura desse novo parque, o que ele agregará, qual será sua extensão, que usos lhe serão garantidos, etc. A resposta a tais questões pode ser enriquecida a partir da análise antropológica e sociológica do Minhocão, que coloca as pessoas, suas relações, ações e visões de mundo no centro do pensamento sobre o urbanismo. Os objetos em contestação sobre essa via elevada não são - isoladamente - sua estrutura de concreto armado, ou as vigas de metal que ainda são valiosas para o Estado nem a poluição que

\footnotetext{
13 Apresentação do grupo Esparrama em janela do Minhocão. <https://www.bloginforma.com.br/ogrupo-esparrama-teatro-na-janela-do-minhocao-esta-de-volta/foto-05/>

14 Minhocão é inaugurado em São Paulo. Disponível em:

<https://efemerides doefemello.com/2016/01/24/minhocao-e-inaugurado-em-sao-paulo/>
} 
invade as casas. A disputa é sobre a definição de espaço público, comum a todos e de uso livre. É uma batalha sobre a vida dos habitantes da cidade e o que eles estão autorizados a fazer, em que lugar e em quais circunstâncias.

\section{A Luta}

Caos, tumulto no conjunto Composição rica de elementos em contraponto

Fuga, Sinfonia.

Povoemos, pois, ovazio penoso Dessa imensa in-diferença Introduzindo entre os homens e sua cidade uma medida proporcional:

Vida.

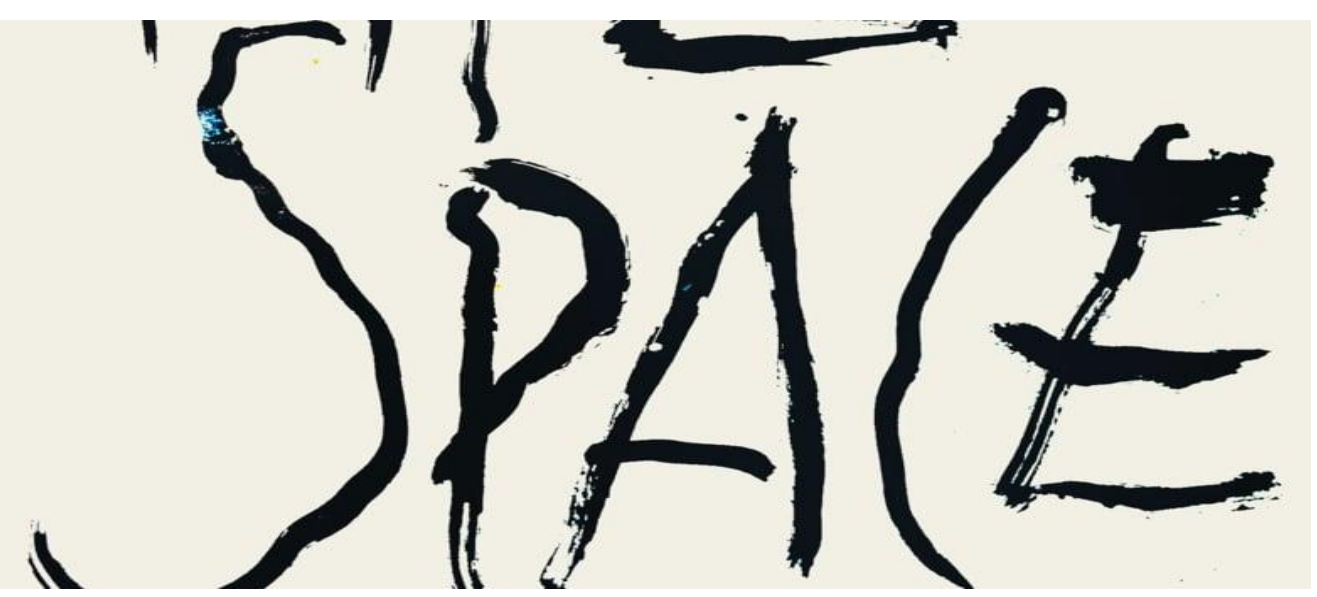

Figura 5. Trecho do registro videográfico da performance "Estado de Jogo", de Lena Kilina, $2018 .{ }^{15}$

A pergunta é: como um viaduto de 3,4 km na cidade de São Paulo se transformou em um parque? Na produção do conhecimento sobre o Minhocão podemos articular noções de urbanismo, arquitetura e geografia, mas estamos falando basicamente sobre as pessoas. Como elas encaram o espaço, o que elas fazem nele. As propostas históricas de um urbanismo orientado para a pura racionalidade dos prédios e economia do

${ }^{15}$ KILINA, Lena. Estado de Jogo. Performance. Disponível em: <https://vimeo.com/295309465> 
espaço, sem envolver as pessoas e suas demandas, criaram desertos nas cidades. Em "A condição pós-moderna" (2012), David Harvey demonstra a falência dos ideais arquitetônicos da modernidade, identificados com a produção e reprodução em série e em massa de mercadorias, pessoas e cidades, que criaram espaços hostis aos humanos, inóspitos para as demandas da sociabilidade e da vida. Não obstante a crítica, esses desertos urbanos produzidos por planejadores e arquitetos continuam a aparecer.

A barbárie das cidades, diz Henri Lefebvre "massiva e selvagem, sem outra estratégia que a maximização dos ganhos, sem racionalidade nem originalidade criadora (...) engendram efeitos desastrosos, observáveis, já constatáveis, de todos os lados. Desde então, em nome da "modernidade" “ (Lefebvre, 2006, p. 04). A razão econômica aplicada ao espaço humano e produzindo desertos, sem participação democrática e consideração das necessidades das pessoas, ocorre no Brasil em exemplos fartos: o bairro da Barra da Tijuca no Rio de Janeiro, sem calçada, sem gente, sem árvores; as cidades condomínio do interior de São Paulo, que existem apenas dentro de muros, onde a ideia de espaço público se restringe à faixa de pedestres, quando muito; o Consórcio Novo Recife, que projeta torres e sombras sobre o Centro Histórico da capital de Pernambuco, importante espaço de reprodução da cultura e da cidadania local; e, naturalmente, o Minhocão na capital paulista.

O estudo sobre o espaço do ponto de vista das ciências sociais traz a atividade humana para o centro do pensamento; há-se de incluir em nossas considerações que essa ação é dimensionada, o que significa que possui implicações maiores ou menores na realidade a depender de quem são os atores concretos em ação (Corrêa, 1999). Na realização do Minhocão, por exemplo, há dois lados atuantes principais: o Estado vinculado a construtoras que juntos realizaram a obra monumental, passando por cima da opinião pública e refazendo o Centro e outros bairros, e os moradores da região e habitantes de São Paulo em geral, que através do uso que deram ao Minhocão e dos vínculos que estabeleceram com a via elevada acabaram por ressignificá-lo, notoriamente ao longo de quase cinco décadas.

O Minhocão e seus arredores também contam um pouco da história do desenvolvimento econômico de São Paulo. Outrora o maior símbolo da opulência burguesa paulistana, a Avenida São João, sobre a qual o Minhocão passa, hoje é conhecida como um endereço inseguro da cidade, apesar do inegável valor 
arquitetônico de seus edifícios. Alguns deles, agora bem juntos do Minhocão, foram construídos como monumento à riqueza dos cafeicultores e industriais, que posteriormente abandonaram o Centro e erigiram para si outros lugares na cidade, como a Avenida Paulista e a Avenida Faria Lima. Também a outrora rica Avenida Amaral Gurgel hoje é encarada como problema social, degradada e escurecida com a chegada do Minhocão, viu seus moradores refugiarem-se em outros endereços.

Já no trecho do Minhocão que vai da Praça Marechal Deodoro até a Avenida Francisco Matarazzo e Barra Funda, podemos observar algo distinto: a valorização dos terrenos e imóveis ao redor do elevado. Esses edifícios são de construção mais recente, surgidos principalmente depois que a via já fora erguida e portanto adaptados para lidar com o colosso de concreto. Os moradores e comerciantes mais antigos contam que na década de 1970 não havia "nada" naquela região. De fato, podemos constatar esse "nada" por fotografias da época e pelas mudanças na ideia que se faz do que é o Centro de São Paulo, que hoje seguramente se estende até o fim do Minhocão de um lado, onde se abre a vista para a Zona Oeste e até depois do Brás, do outro lado, na região leste. Hoje poucos paulistanos hesitariam em dizer que o Minhocão fica no Centro, enquanto do ponto de vista político-administrativo ele percorre diferentes bairros.

Esse tipo de continuidade e descontinuidade percebida pelos habitantes da cidade se liga à ordem distante, da reprodução do sistema econômico, que altera o vivido localmente, pertencente a condições materiais e históricas específicas. Onde antes havia o "nada" entre o Centro e a Barra Funda hoje existe a continuidade criada com a chegada do Minhocão. Ao se caminhar pelo piso superior da via e se observar as diferenças entre os edifícios, evidenciam-se distinções entre os períodos de ocupação, que se fazem notar pelo aspecto dos prédios - mais ou menos neoclássicos, mais ou menos pós-modernos, mais ou menos modernista - e também por um detalhe insólito: a distância que as construções estão em relação a pista do elevado.

Os edifícios construídos posteriormente à instalação do Minhocão foram planejados para lidar com os já conhecidos problemas de poluição, barulho, calor, perda de privacidade que a obra trouxera, e foram erguidos com maior distância em relação à via, utilizando a parte da frente do terreno para finalidades como estacionamento, jardim, playground, etc. Outra solução encontrada pelos construtores foi edificar torres 
mais altas, que nos primeiros andares oferecem serviços e comércio aos moradores, que habitam os pisos superiores, distantes dos incômodos trazidos pelo Minhocão.

As diferenças percebidas na ocupação da cidade através da observação dos tipos de prédios e da diversidade de espaços nos mostra que ela não é um todo harmônico, mas possui fraturas nascidas do desenvolvimento das relações de produção e das contradições sociais. Diante da quebra da totalidade e linearidade, Benjamin (2007) aposta no estudo dos fragmentos como forma de conhecimento urbano, que se articula com o total através da mediação dos conflitos entre os interesses das pessoas - que realizam a diversidade urbana - e os interesses da reprodução do sistema de produção - homogeneizantes. A criação do Parque Minhocão pelos habitantes da cidade é possível por meio de estratégias de "desobediência" ao sistema dominante, representado, neste caso, pela prefeitura municipal.

Foram criadas, então, ao longo de décadas, associações de moradores organizados para reivindicar perante a municipalidade suas principais demandas: conservação da parte de baixo do Minhocão, que está degradada, regulação e redução do horário de funcionamento da pista para veículos, segurança pública e, cada vez com mais força, a criação do parque. Esses grupos organizados que reivindicam o Minhocão como espaço público na cidade são atores centrais no processo de criação do parque, pois ao realizarem atividades no elevado - como apresentações artísticas, manifestações políticas, eventos esportivos - trazem mais gente para o viaduto, que o utilizam como o parque e legitimam seu reconhecimento como algo no qual ele já se transformou: espaço público, de arte, esporte e lazer.

Vimos que a própria permanência no espaço urbano aberto se dá por dentro da contestação política, pois a mera possibilidade de estar nos lugares e nele permanecer não está garantida, devido ao conflito de interesses sobre as definições do espaço e usos a ele atribuídos (Campos, 2017). Atualmente, após a confirmação legal da criação do Parque Minhocão, as maiores disputas se dão em relação a extensão desse parque, e de que maneira ele irá afetar a vida dos moradores dos prédios que o ladeiam. Por mais surpreendente que possa parecer, há quem prefira o barulho de carros ao barulho de gente, e houve oposição ao longo das décadas à ideia da criação de um parque público - ponto hoje já superado com a promulgação da Lei 16.833/2018. Hoje a pauta de grupos contrários ao Parque Minhocão é a demolição de parte do elevado e a transformação 
do trecho restante em parque elevado; essa ideia pode sercontestada mas é executável, uma vez que a estrutura do Minhocão - montável e desmontável - admite recorte em seus 3,4 km de extensão.

As divergências expressadas pelos habitantes da cidade acerca do destino do Minhocão são saudáveis e sinalizam "projetos legítimos em conflito permanente por novas configurações sociais exigindo e conciliando para sobreviver ou, simplesmente, trabalhar, comer, reproduzir e educar" (Guedes, 2003, p. 76). A importância da diferença de pontos de vista sobre os usos do espaço público fica ressaltada se lembrarmos que na origem do Minhocão está o silenciamento da opinião pública por um governo autoritário. Ao contrário da agressiva e ruidosa imposição de seu nascimento, o Minhocão adquiriu significado e vida de forma sutil e quase silenciosa ao longo de um vasto período de tempo para os moradores de São Paulo, e também por isso sua existência como parque já está consolidada, pois é profunda. No entanto, é preciso estar atento para ameaça de retorno a períodos não democráticos - como o que vivemos no momento da escrita e leitura deste texto - nos quais o uso livre dos espaços urbanos abertos é restringido e se perde o direito à cidade e à cidadania, compreendida como qualidade da liberdade do habitante da pólis.

\section{Considerações finais}

Como saber, como saber, como saber o que é meu?

Lena Kilina, 2018

Em Agosto de 2018 ocorreu a performance "Estado de Jogo", de autoria da antropóloga e artista Lena Kilina, no Espaço Bréu, Barra Funda, como parte de sua pesquisa pós-doutoral sobre a emergência de espaços públicos e democráticos no Brasil e na China. A apresentação buscou expressar o conhecimento antropológico e sociológico sobre o Minhocão em linguagem artística, trazendo para o palco suas cores, sons, movimentos e tudo quanto a autora capta desse fenômeno, com o qual encontra paralelo do outro lado do mundo. Lena apresentou o conceito de "estado de jogo" para se referir ao que vivencia no Minhocão: estratégias criativas para permanência no 
espaço e trânsito entre saberes e definições, expressando um estado em que a cidade nunca está pronta, e sim em construção - em jogo - como seus moradores.

A ideia de jogo atribuída às atividades desenvolvidas no Minhocão elucida dois aspectos centrais para se pensar o elevado do ponto de vista deste artigo: o fato de que suas definições estão em movimento, em disputa (em jogo) e as características lúdicas das atividades que nele ocorrem, majoritariamente arte e esportes ou simplesmente estar aí. O estado de jogo seria a resposta criativa dos habitantes da cidade para uma situação desconfortável, geralmente não democrática e que se relaciona à construção do meio humano (a segunda natureza de Lefebvre, o labirinto de Walter Benjamin), enfatizando que hoje sua ocorrência oscila entre lógicas excludentes e privadas e aquelas coletivas e públicas; sendo que o estado jogo tende para a criação de novos espaços através de apropriações livres e democráticas.

Encontramos vestígios desse jogo por todo o percurso sobre o Minhocão, que apesar de ser constituído basicamente por duas vias de asfalto, revela sinais das pessoas que passaram por ali. Às vezes esses indícios são reconhecíveis por cartazes com conteúdo político colados na madrugada, ou por garrafas de vidro vazias e pontas de cigarro que atestam a confraternização da noite anterior, objetos caídos e esquecidos, imagens pintadas no chão e nos postes de iluminação, basicamente os dois únicos elementos - afora os humanos e sua presença - ao longo de 3,4 km de extensão. 


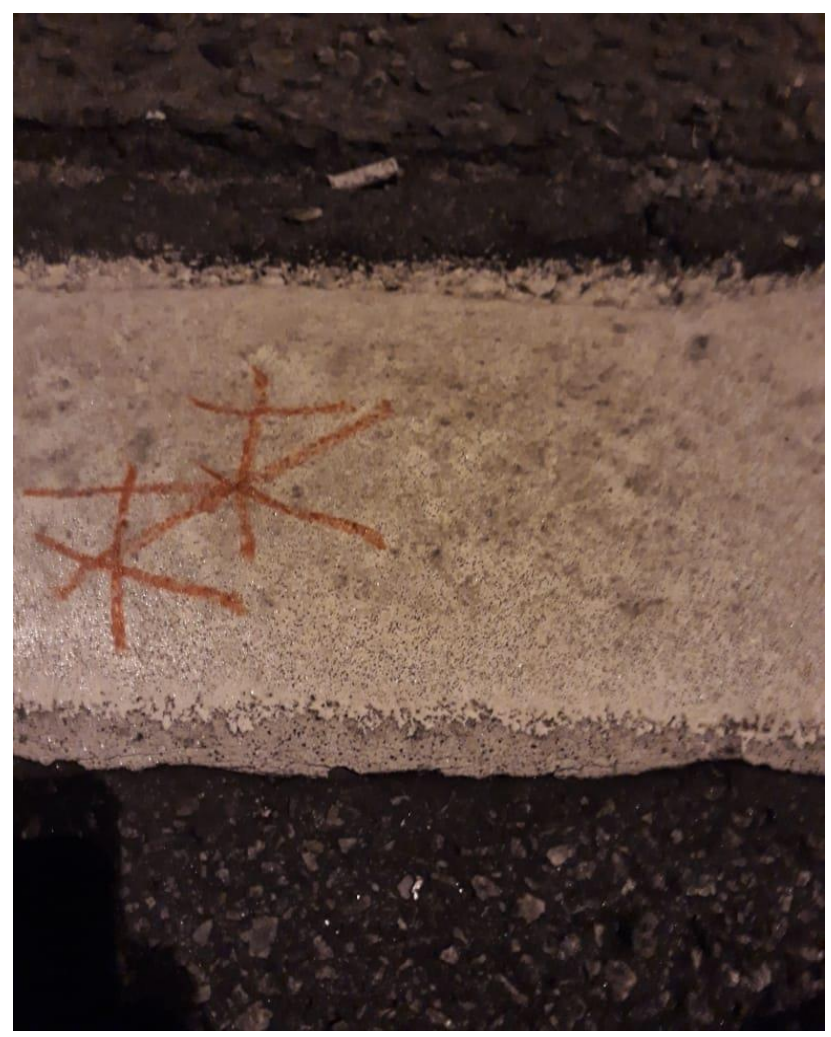

Figura 6. Assinatura humana feita no chão do Minhocão durante a noite, período em que se encontra aberto para os pedestres. ${ }^{16}$

Apontamos neste artigo que usos reais que as pessoas fazem dos espaços são determinantes para a emergência de sua definição e para a caracterização de suas qualidades, que podem ser distintas do status oficial, político-administrativo, que possui. Os usos mostram que um espaço pode ter significados diversos para pessoas diversas em ocasiões distintas e que seus atributos surgem na interação e se consolidam no tempo, com a potência de transformar definitivamente espaços privativos em espaços públicos e ampliadores da cidadania.

Procuramos, assim, demonstrar que a vitalidade urbana é tão maior quanto maior é engajamento dos moradores com os espaços em que vivem. $\mathrm{O}$ uso das áreas abertas e disponíveis carrega a possibilidade da criação da cidade, de sua ampliação física e simbólica, pois que ela não é constituída unicamente de atributos sólidos e geométricos, mas possui, também, uma dimensão humana, plástica, pois “a matéria é magia, porque

\footnotetext{
16 Tag de Renan Ribeiro de Figueiredo
} 
Dossiê | Emergência urbana: criação de espaço público e o nascimento do "parque minhocão" na cidade de São Paulo (CAMPOS, João Pedro)

permite a eclosão de vida social, ela cria vida" (Guedes, 2003, p.76) através do es paço e no espaço que, assim como a humanidade, não se mantém permanente ${ }^{17}$.

\section{Bibliografia}

ARGAN, Giulio Carlo. História da arte como história da cidade. Tradução de Pier Luigi Cabra. São Paulo: Martins Fontes, 1995.

BENJAMIN, Walter. Charles Baudelaire: um lírico no auge do capitalismo. São Paulo: Brasiliense, 2000.

BENJAMIN, Walter. Passagens. Belo Horizonte: Editora UFMG; São Paulo: Imprensa Oficial, 2007.

CAMPOS, João Pedro de Lima. Circuito-circunscrito: apontamos sobre arte de rua e a viração de poetas no Rio de Janeiro. In: Revista PROA de Antropologia e Arte. V.7. Campinas: Unicamp, 2017.

COLE, Ariane Daniela. A cidade em processo. Revista Pós no 22. São Paulo: USP, 2008.

CORRÊA, Roberto Lobato. O Espaço Urbano. São Paulo: Ática, 1999.

GUEDES, Joaquim. Cidade e espaço político. In: Revista Psicologia USP. São Paulo: USP, 2003.

HARVEY, David. Condição pós-moderna: uma pesquisa sobre as origens da mudança cultural. 23 ed. São Paulo: Loyola, 2012.

LEFEBVRE, Henri. A produção do espaço. Trad. Doralice Barros Pereira e Sérgio Martins. Do original: La production de l'espace. 4e éd. Paris: Éditions Anthropos, 2000. LEFEBVRE, Henri. O direito à cidade. São Paulo: Centauro, 2001.

JACOBS, Jane. Morte e vida das grandes cidades. São Paulo: Martins Fontes, 2011. LYNCH, Kevin. A imagem da cidade. São Paulo: Martins Fontes, 1999.

MARX, Karl. O Capital: crítica da economia política. São Paulo: Boitempo, 2017.

\footnotetext{
17 Em fevereiro de 2019, alguns meses após a finalização deste artigo, o então prefeito de São Paulo, Bruno Covas (PSDB), determinou o início das obras de adaptação do Minhocão para sua definitiva instalação como parque público. É previsto que ao longo do ano o tráfego de veículos seja totalmente interrompido e que seu primeiro trecho como parque seja concluído até 2020 . 0 espaço, como vimos, não se mantém permanente, sua transformação pode ser mais acelerada que o tempo de produção de um artigo.
} 
MONTE, Marisa. Gentileza. In: Memórias, Crônicas e Declarações de Amor. Rio de Janeiro: Phonomotor Records/EMI, 2000.

ROCHA, Ana Luísa; ECKERT, Cornélia. Etnografia da duração: antropologia das memórias coletivas em coleções etnográficas. Porto Alegre: Marca Visual, 2013.

VAINER, Carlos ... [et. al]. Cidades Rebeldes: passe livre e as manifestações que tomaram as ruas do Brasil. São Paulo: Boitempo, 2013.

VELOSO, Gil. Um viaduto chamado Minhocão. Mairiporã: Dedo de Prosa, 2015. 